\title{
Canine juvenile cellulitis: a retrospective study (2009-2016)
}

\section{Celulite juvenil canina: Estudo retrospectivo (2009-2016)}

\author{
José Artur Brilhante BEZERRA루 ; Julianna Pereira da Silva SANTOS²; Kilder Dantas FILGUEIRA³ \\ ${ }^{1}$ Universidade Federal Rural do Semi-Árido, Programa de Pós-Graduação em Ciência Animal, Mossoró - RN, Brazil \\ ${ }^{2}$ Clínica Veterinária Nobreza Canina, Mossoró - RN, Brazil \\ ${ }^{3}$ Universidade Federal Rural do Semi-Árido, Hospital Veterinário Jerônimo Dix-Huit Rosado Maia, Mossoró - RN, Brazil
}

\begin{abstract}
Juvenile cellulitis (JC) is an uncommon vesiculopustular disease that affects dogs, especially those under four months of age. The aim of the present study was to characterize the epidemiological, clinical, and therapeutic profile of JC based on clinical records of canine patients treated at the Veterinary Hospital of the Universidade Federal Rural do Semi-Árido, between the years 2009 and 2016. A total of five cases were diagnosed. Four dogs presented at an average age of two months and 22 days and were crossbred; the other dog was a rottweiler aged 38 weeks. The average time of evolution of the disease was 16 days, and the main clinical signs were edema, papules, pustules, and bilateral ocular discharge. The diagnosis was confirmed by cytology in four animals and by histopathology in only one patient. For all dogs, the treatment was based on cephalexin, administered for 30 days, and prednisolone for three weeks. Otological therapy was included when necessary. Four cases had a favorable outcome. JC is a rare dermatopathy that deserves special attention from veterinary practitioners.
\end{abstract}

Keywords: Sterile granulomatous dermatites. Canis familiaris. Dermatology.

\section{Resumo}

A celulite juvenil (CJ) é uma doença vesiculopustular incomum que acomete cães principalmente na faixa etária inferior aos quatro meses. Este trabalho analisou o perfil epidemiológico, clínico e terapêutico da CJ em cães a partir da casuística do Hospital Veterinário da Universidade Federal Rural do Semi-Árido, referente aos anos de 2009 a 2016. Cinco casos foram diagnosticados, incluindo quatro cães (80\%), sem raça definida e com idade média de dois meses e 22 dias, e um da raça Rottweiler (20\%) com 38 meses de idade. O período evolutivo médio das lesões foi de 16 dias e os principais sinais clínicos observados foram edema, pápulas, pústulas e secreção ótica bilateral. O diagnóstico foi confirmado por citologia (80\%) e histopatologia (20\%). Em todos os animais, o tratamento consistiu de cefalexina, administrada por 30 dias, e prednisolona, por três semanas. A terapia otológica tópica foi incluída quando necessária. Em quatro casos o desfecho clínico foi favorável. A CJ é uma dermatopatia rara que merece atenção especial dos clínicos veterinários.

Palavras-chave: Dermatite piogranulomatosa estéril. Canis familiaris. Dermatologia.

Correspondence to:

José Artur Brilhante Bezerra

Universidade Federal Rural do Semi-Árido, Hospital

Veterinário Jerônimo Dix-Huit Rosado Maia

Av. Francisco Mota, 572

CEP 59625-900, Mossoró, RN, Brazil

e-mail: artur_brilhante@hotmail.com

Received: 16/06/2017

Approved: 19/10/2017

\section{Introduction}

Juvenile cellulitis (JC), also known as juvenile sterile granulomatous dermatitis and lymphadenitis, is an uncommon vesiculopustular dermatosis of pediatric dogs (MILLER et al., 2013). It usually affects animals that are less than four months of age, although there are reports of this disease occurring in adult dogs (JEFFERS et al., 1995; NEUBER et al., 2004). Despite the efforts to find an underlying cause for this disorder, its exact etiopathogenesis is not elucidated, and the most widespread hypothesis attributes the disease to an immune-mediated cause associated with genetic factors (PARK et al., 2010; MILLER et al., 2013).

The main clinical signs are papules, pustules, alopecia, swollen face, and crusts located on the facial region, especially on the eyelids, lips, and muzzle. Bilateral otitis and submandibular lymphadenopathy may also be observed. Some dogs may present nondermatological manifestations, such as lethargy, hyporexia, pyrexia, and lameness (WHITE et al., 1989; SCOTT; MILLER JUNIOR, 2007; MILLER et al., 2013). 
The diagnosis of JC is based on clinical findings and cytological or histopathologic evaluations of the affected tissue. A pyogranulomatous reaction is generally observed microscopically, with absence of microorganisms (NEUBER et al., 2004).

Early and aggressive therapy for JC is necessary. Corticosteroids are the drugs of choice and antibiotics are included when secondary bacterial infection is present. The prognosis for canine JC is considered good if adequate treatment is instituted (FONSECA-ALVES et al., 2012; MILLER et al., 2013).

Isolated descriptions of this disease are well documented, but the compilation of a series of cases is very scarce, especially in Brazil. Thus, the aim of the present investigation was to describe the clinical, epidemiological, and therapeutic profile of canine JC in a retrospective study conducted in a veterinary teaching hospital.

\section{Material and Methods}

A retrospective study was performed, analyzing the clinical records of canine patients treated at the Veterinary Teaching Hospital at the Universidade Federal Rural do Semi-Árido (UFERSA, Mossoró, Rio Grande do Norte, Brazil) from 2009 to 2016 . Cases with a confirmed diagnosis of juvenile cellulitis were selected, and the medical records were reviewed to collect individual information, such as sex, age, breed, evolution time of the disease, clinical signs, complementary diagnosis methods used, treatment, and outcome of the patients. Data were presented as mean and frequency.

\section{Results}

During the study period a total of five dogs were diagnosed with JC, of which three were males and two were females. Four patients were pediatric, with an average age of two months and 22 days. Only one dog was an adult, aged 38 months. In terms of breed, four animals were crossbred, and one was a rottweiler. The average evolution time of the lesions was 16 days. Information regarding the epidemiological characterization is presented in table 1.

Table 1 - Epidemiological characterization of the five dogs with juvenile cellulitis diagnosed at the Veterinary Teaching Hospital at the Universidade Federal Rural do Semi-Árido (UFERSA, Mossoró, Rio Grande do Norte, Brazil) from 2009 to 2016

\begin{tabular}{lccc}
\hline Case & Breed & Age (months) & Sex \\
\hline $\mathbf{1}$ & Crossbred & 1 & Female \\
$\mathbf{2}$ & Crossbred & 1 & Male \\
$\mathbf{3}$ & Crossbred & 2 & Male \\
$\mathbf{4}$ & Crossbred & 3 & Male \\
$\mathbf{5}$ & Rottweiler & 38 & Female \\
\hline
\end{tabular}

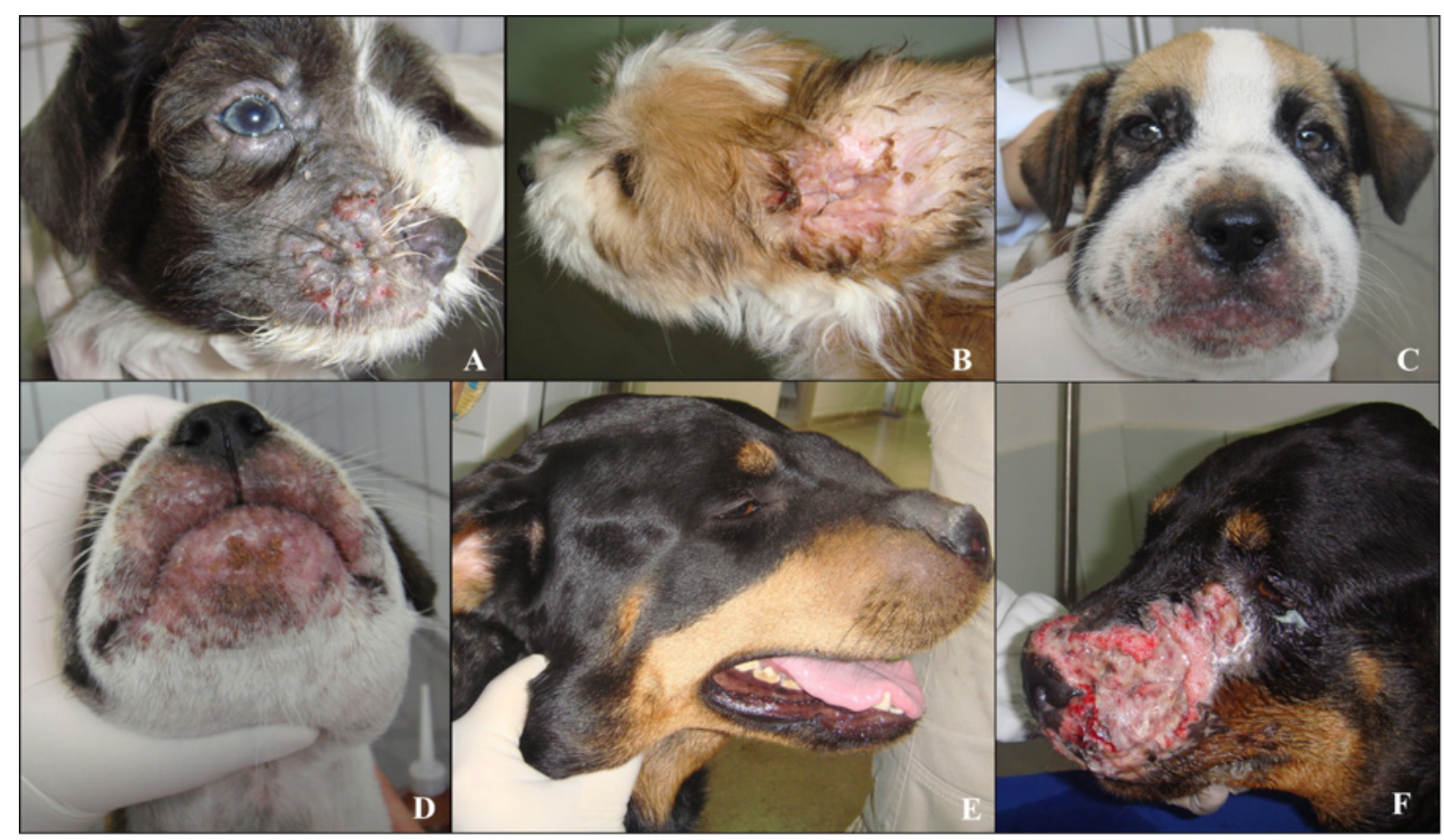

Figure 1 - Clinical signs presented by the dogs with juvenile cellulitis diagnosed at the Veterinary Teaching Hospital at the Universidade Federal Rural do Semi-Árido (UFERSA, Mossoró, Rio Grande do Norte, Brazil) from 2009 to 2016. A. Papules and pustules on the lips and periocular alopecia; B: Otitis externa; C: Facial swelling; D: Swelling, erythema, and meliceric crusts on lips and chin; E: Nasal swelling and submandibular lymphadenomegaly in a 38-week patient; F: Evolution of figure 1E to skin ulceration 
The main clinical sign observed was facial swelling, occurring in all of the five animals. Papules, pustules, and bilateral otic discharge were seen in four, while erythema, submandibular lymphadenopathy, and alopecia were seen in two. Necrosis and ulcerated areas were observed in only one case. The most affected locations were the eyelids, lips, and chin in four animals. Nasal lesions were present in one dog. Clinical characterization of the studied animals is shown in figure 1 and table 2.

Cytology was used to confirm the presumptive diagnosis in four animals, while histopathology was only necessary in the adult dog. Figure 2 presents the cytopathological and histopathological findings.
Table 2 - Clinical characterization of the five dogs with juvenile cellulitis diagnosed at the Veterinary Teaching Hospital at the Universidade Federal Rural do SemiÁrido (UFERSA,Mossoró, Rio Grande do Norte, Brazil) from 2009 to 2016

\begin{tabular}{lccc}
\hline Case & $\begin{array}{c}\text { Distribution of } \\
\text { skin lesions* }\end{array}$ & Clinical signs** & $\begin{array}{c}\text { Diagnosis } \\
\text { method }\end{array}$ \\
\hline $\mathbf{1}$ & ED, L, E, C & S, PA, PU, OD & Cytopathology \\
$\mathbf{2}$ & ED, L, E, C & S, PA, PU, OD, SL, ER, A & Cytopathology \\
$\mathbf{3}$ & ED, L, E, C & S, PA, PU, OD & Cytopathology \\
$\mathbf{4}$ & ED, L, E, C & S, PA, PU, OD, SL, ER, A & Cytopathology \\
$\mathbf{5}$ & N & S, U, NE & Histopathology \\
\hline
\end{tabular}

${ }^{*}$ ED: eyelid; L: lips; E: ear: C: chin; N: nose ${ }^{* *}$ S: swelling; PA: papule; PU: pustule; OD: otic discharge; SL: submandibular lymphadenopathy; ER: erythema; A: alopecia; U: ulceration; NE: necrosis

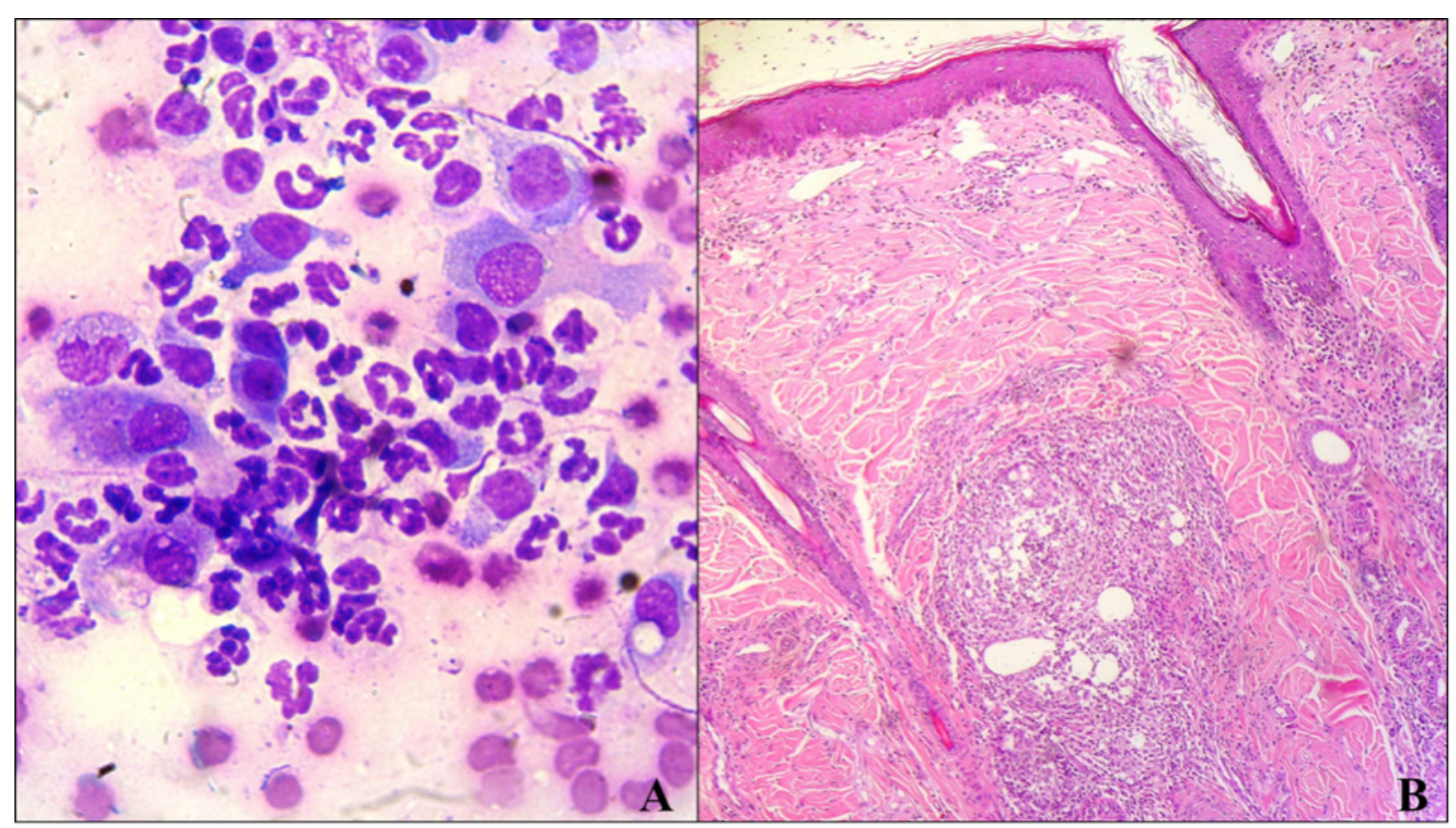

Figure 2 - Cytopathological findings of pustular content from an animal with juvenile cellulitis diagnosed at the Veterinary Teaching Hospital at the Universidade Federal Rural do Semi-Árido (UFERSA, Mossoró, Rio Grande do Norte, Brazil) from 2009 to 2016. A: Multiple neutrophils and macrophages are observed, with no bacteria or other microorganisms (100 x magnification, Diff-quick staining); B: Histopathologic photomicrography showing perifollicular pyogranulomas at the center (10 x magnification, hematoxylin, and eosin staining)

For all dogs, the systemic therapy prescribed was cephalexin (30 mg/kg every $12 \mathrm{~h}$ for 30 days) and prednisolone for three weeks, beginning with a dose of 2 $\mathrm{mg} / \mathrm{kg}$ every $24 \mathrm{~h}$, followed by gradual reduction. Animals with external otitis also received topical therapy. The case 5 , the adult dog, presented a satisfactory response during the first 21 days of treatment. After the discontinuation of the drugs, lesions relapsed rapidly. The treatment with corticosteroids and antibiotics was reestablished, nevertheless, the affected area became extensively ulcerated, necrotic, painful, with secondary bacterial infection, and poorly responsive to the therapeutic options used.
The outcome was favorable for pediatric dogs, with remission of symptoms after three weeks of treatment, and with no reports of relapse. Nevertheless, euthanasia of the adult patient was requested by the owner after 54 days of treatment due to the severity of the lesions that developed on the animal's face as the disease progressed.

\section{Discussion}

JC is considered an uncommon disease (MILLER et al., 2013). In a reference veterinary dermatology service, it represented only $0.1 \%$ of the cases during a 30 -year period (SCOTT; MILLER, 2007). During the eight years analyzed in 
the present study, less than one case per year was registered, which reinforces the unusual pattern of this dermatopathy. Due to the infrequent nature of this cutaneous disease, only a few manuscripts on this topic are available, especially in terms of retrospective studies. We found only two published papers of this nature, with 18 and 15 cases treated over periods of 21 and 11 years, respectively, both performed in small-animal dermatology reference centers (WHITE et al., 1989; SCOTT; MILLER, 2007).

As shown in other studies the incidence of JC was higher in male dogs (MASON; JONES, 1989; SCOTT; MILLER, 2007). The average age of the patients was also in accordance with the data found in the literature (MILLER et al., 2013). The detection of JC in an adult animal in the current research was in accordance with previous descriptions that reported the occurrence of this tegumentary pathology in canines aged two to four years, although less frequently (JEFFERS et al., 1995; NEUBER et al., 2004). Diagnosis of JC in older animals is challenging, since it is an unusual condition among adult animals (FILGUEIRA et al., 2014).

Some breeds are considered to be predisposed to JC, including the golden retriever, dachshund, labrador, beagle, pointer, and rottweiler (SCOTT; MILLER, 2007). In the current research, only one animal - the rottweiler - had a defined breed, and it is on the list of those breeds predisposed to JC. The majority of the animals was crossbred and probably genetically predisposed to the development of JC. Besides the possible genetic etiology, it is postulated that JC may be caused by the distemper virus, allergic reactions, poor hygiene, poor nutrition, endoparasites, and stress (SCOTT; MILLER, 2007).

The average evolution time of the disease in the animals in the present study was similar to that observed by Scott and Miller (2007), between 0.5 and 4 weeks. The symptomatology manifested by the dogs was consistent with previous descriptions by White et al., 1989; Scott; Miller, 2007; FonsecaAlves et al., 2012; Miller et al., 2013. The presence of cellulitis in young animals, which is represented by areas of dermal or subcutaneous phlogosis, is characteristic of JC and should lead veterinarians to suspect the presence of the condition. While the diagnosis of JC is primarily based on clinic examination, cytological and histopathological analyses of the lesions are necessary for its confirmation (SCOTT; MILLER, 2007).

It was demonstrated that the diagnosis of JC may be established in most cases with simple and inexpensive techniques, such as cytopathology. Histopathology is essential when the clinical and cytological findings are not enough for a conclusive diagnosis, especially in mature dogs, as demonstrated in the present study (MILLER et al., 2013). Angioedema, demodicosis, severe bacterial pyoderma, and adverse cutaneous drug reactions are other diagnoses that must be considered in cases of JC (SCOTT; MILLER, 2007).

Treatment based on a corticosteroid and an antibiotic promoted the resolution of all pediatric cases, agreeing with other researchers, according to whom the majority of patients recovered under this therapy within three weeks (SCOTT; MILLER, 2007; FONSECA-ALVES et al., 2012). In the adult dog analyzed (case 5) the reduced response to the steroidal anti-inflammatory drugs reflected refractoriness to such immunosuppressive therapy. Euthanasia was requested by the owner due to the severity of lesions, which became necrotic, ulcerated, very painful, and infected. The inclusion of other immunosuppressive drugs was suggested, but the animal's owner refused. The outcome could have been favorable if the treatment proposed had been instituted. Some authors have reported other satisfactory therapeutic options, including griseofulvin used as an immunomodulatory drug, and the combination of prednisolone with cyclosporine (MIURA et al., 2005; PARK et al., 2010).

\section{Conclusion}

Canine JC is a rare dermatopathy that requires appropriate epidemiological, clinical, and laboratorial knowledge for the practitioner to reach the diagnosis and establish an ideal therapeutic protocol. It is important to highlight that although the disease nomenclature implies that JC affects only pediatric animals, adult dogs may also be affected.

\section{References}

FILGUEIRA, K. D.; WALLER, S. B.; MACÊDO, L. B.; REIS, P. F. C. C. Celulite juvenil canina com apresentação atípica de faixa etária. Medvep Dermato: Revista de Educação Continuada em Dermatologia e Alergologia Veterinária, v. 3, n. 8, p. 50-51, 2014.
FONSECA-ALVES, C. E.; CORREA, A. G.; COSTA, H. X.; ELIAS, F.; SANTOS JUNIOR, H. L.; COSTA, S. S.; CALAZANS, S. G. Celulite juvenil canina: relato de casos. Semina: Ciências Agrárias, v. 33, n. 4, p. 1539-1542, 2012. doi: 10.5433/1679-0359.2012v33n4p1539. 
JEFFERS, J. G.; DUCLOS, D. D.; GOLDSCHMIDT, M. H. A dermatosis resembling juvenile cellulitis in an adult dog. Journal of the American Animal Hospital Association, v. 31, n. 3, p. 204-208, 1995. doi: 10.5326/15473317-31-3-204.

MASON, I. S.; JONES, J. Juvenile cellulitis in Gordon setters. The Veterinary Record, v. 124, n. 24, p. 642, 1989.

MILLER, W. H.; GRIFFIN, C. E.; CAMPBELL, K. L. Muller \& Kirk's small animal dermatology. 7. ed. St. Louis, MO: Elsevier, 2013.

MIURA, H.; NAKAMURA, T.; SHIBATA, K.; NAGATA, M. Canine juvenile cellulitis successfully treated with griseofulvin in a dog. The Japanese Journal of Veterinary Dermatology, v. 11, n. 1, p. 9-12, 2005. doi: 10.2736/jjvd.11.9.

NEUBER, A.E.; VAN DEN BROEK, A. H.; BROWNSTEIN, D.; THODAY, K. L.; HILL, P. B. Dermatitis and lymphadenitis resembling juvenile cellulitis in a four-yearold dog. Journal of Small Animal Practice, v. 45, n. 5, p. 254-258, 2004. doi: 10.1111/j.1748-5827.2004.tb00232.x.

PARK, C.; YOO, J.-H.; KIM, H.-J.; KANG, B.-T.; PARK, H.-M. Combination of cyclosporin A and prednisolone for juvenile cellulitis concurrent with hindlimb paresis in 3 English cocker spaniel puppies. Canadian Veterinary Journal, v. 51, n. 11, p. 1265-1268, 2010.

SCOTT, D. W.; MILLER JUNIOR, W. H. Juvenile cellulitis in dogs: a retrospective study of 18 cases (1976-2005). The Japanese Journal of Veterinary Dermatology, v. 13, n. 2, p. 71-79, 2007. doi: 10.2736/jjvd.13.71.

WHITE, S. D.; ROSYCHUK, R. A.; STEWART, L. J.; CAPE, L.; HUGHES, B. J. Juvenile cellulitis in dogs: 15 cases (1979-1988). Journal of the American Veterinary Medical Association, v. 195, n. 11, p. 1609-1611, 1989. 